\title{
DIASTATIC ACTIVITY OF THE BLOOD IN CANCER, SYPHILIS AND DIABETES*
}

\author{
H. H. DeNIORD, M.D., ANd B. F. SCHREINER, M.D. \\ BUFFALO
}

Some interesting observations were made by V. C. Meyers and J. A. Killian ${ }^{1}$ on the diastatic activity of the blood, and we have for some months past included an estimation of the diastatic activities of the blood in our routine complete blood studies. We have followed the method of Lewis and Benedict for blood sugar estimation and that of Meyers and Killian for the diastatic activity in the blood, being exact in the period of incubation, and beginning the blood chemistry work within ten minutes after the withdrawal of blood from the vein.

In the routine studies of the blood of cancer patients of the State Institute for the Study of Malignant Disease we have accumulated considerable data on other estimable blood factors, but in this short paper we are reporting only on the Wassermann reaction, diastatic activity and sugar content of the blood, and the effect of roentgen-ray treatments on these factors. We have also included in our report similar studies of diabetics and nephritics, eclamptics, cases of general fatigue and overwork, and normal people. The most interesting of our observations have been those made in our studies of the cases of diabetes, in the behavior of the diastatic activity of the blood. After an observation of a large series of cases we have taken this factor to be normal up to an activity of 40 .

DIASTATIC ACTIVITY OF THE BLOOD IN GLYCOSURIA

Glycosuria may be divided into four groups:

(a). La piqure of Claude Bernard.

(b). Alimentary glycosuria.

(c). Phloridzin diabetes.

(d). Pancreatic diabetes.

(a). Claude Bernard, the originator of la piqure, has shown unquestionably the relation of injury of a group of medulla cells to glycosuria. This type is unobtainable in a starving animal and is entirely dependent on glycogenolysis. It has been attributed to sudden flushing of the liver with blood, causing a rapid conversion of glycogen

* From the New York State Institute for the Study of Malignant Disease. Buffalo. N. Y., H. R. Gaylord, M.D.. Director.

1. Meyers and Killian: Jour. Biol. Chem. 29:179, 1917. 
to sugar. It may be due to a sudden activation of diastase in the blood, from some source or other, stimulated by the injury to the nerve tissue; or to a lowering of the threshold of excretion of sugar in the kidneys.

Much remains to be said about hyperglycemia in this type of glycosuria.

(b) Alimentary glycosuria is frequent in its occurrence, appears with an intestinal stasis and toxemia with poor oxidation, and disappears on correction of these ailments. It may exist with quite normal kidneys with a glycemia of but 150 to $200 \mathrm{mg}$. of dextrose per 100 c.c. of blood, and in nephritis the dextrose may arrive at a concentration of 200 to $400 \mathrm{mg}$. before it begins to be excreted, depending on the severity of the renal lesion. It is possible that putrefaction products in constipation cause an inhibition of glycogenesis or a much inhibited sugar utilization. Further investigation of ferment activity is needed to throw light on this subject.

(c) Phloridzin diabetes, purely an experimental type, suggests only the changes possible in the permeability of renal cells to different blood factors, and adds strength to the much discussed question of selective retention of the various products normally excreted by the kidneys from the blood.

Loewi ${ }^{2}$ believes that it converts colloidal blood sugar into diffusible blood sugar, resulting in an immediate diffusion through the renal cells, which are unaffected by the phloridzin. Stiles and Lusk ${ }^{3}$ have shown that dextrose, uniting with the colloidal radical in the blood, is not burned, and that dextrose injected subcutaneously reappears in the urine. On the other hand, Rosenfeld and Asher ${ }^{4}$ find blood sugar readily diffusible. Therefore, the action of phloridzin must be in increasing the permeability of the renal cell membranes, rather than in altering the chemical state of the sugar.

To digress somewhat on the subject of phloridzin glycosuria, consider for a minute the question of permeability of membranes and the important bearing it must have on carbohydrate metabolism. The carbohydrates of the food are absorbed into the portal circulation as a monosaccharid, and some of this is stored as the polysaccharid, glycogen, in the liver. A portion not stored here is deposited in the muscles also as glycogen; a part of it is utilized immediately by the tissues for work and heat; some glucose remains in the blood stream for the maintenance of the normal concentration of sugar in the blood. Normally, on absorption of sugar there is an immediate stimulus to storage of this material in the tissue cells. The so-called "stimulus" must be merely a mechanical factor of the fluid on the outside of the

2. Loewi: Arch. f. exper. Path. u. Pharmakol. 48:410, 1902.

3. Stiles and Lusk: Science of Nutrition, p. 274.

4. Rosenfeld and Asher: Zentralbl. f. Physiol. 14:449, 1905. 
cell membranes becoming hyper-isotonic to the fluid inside, and the membrane being wholly permeable to sugar admits it until the fluids are again isotonic, or in balance. This process is shortened by the burning of some of the sugar, and the time covered by the entire procedure is two to three hours, when the normal level of the blood sugar is reached. At the moment this occurs, a reverse process begins. The blood sugar continues to be burned, which makes the blood hypoisotonic to the cell fluid and osmosis reverses, with active glycogenolysis, until food ingestion adds a fresh supply of sugar to the blood. There is then a constant flow of sugar molecules either into or out of the cell, with possibly other substances permeable through this membrane.

With a persistent hyperglycemia and no glycogen storage, there undoubtedly is some change in the cell membrane which converts it to a membrane semipermeable to sugar and prevents its storage.

In phloridzin diabetes the renal cell membrane must undergo some change which, on the other hand, converts it from a semipermeable to a perfectly permeable membrane.

In alimentary glycosuria the hyper-isotonic state of the sugar of the blood to that of the tissue cells raises considerable osmotic pressure, which may stimulate the renal cells so that sugar is excreted. The point of osmotic tension at which glycosuria commences varies with the individual, and depends considerably on the state of the kidney and whether it is normal; so that in varying degrees of nephritis, the osmotic pressure of the sugar in the blood must rise higher in order to have a glycosuria. The patient begins to excrete sugar as soon as the threshold of excretion of that material is reached. $\mathrm{He}$ also responds with exactness to restriction of carbohydrates in his diet until the sugar in his blood becomes normal, when there is once more a normal balance in glycolysis and glycogenolysis and a distinct relief of the irritating high osmotic pressure on the renal cells. This relieves the irritating symptoms of polyuria so common to glycosuria, and especially in chronic interstitial nephritis.

The question resolves itself into what can change the permeability of a membrane? The agent in the blood that does this cannot be incorporated in fixed tissue cells, but must be an internal secretion carried by the blood. All tissues contain diastase, but not all of them contain activators of this ferment. The one tissue which we know contains both is the blood.

(d). Pancreatic diabetes has long been a subject of research, and we are little farther advanced than Claude Bernard left us in 1856. Von Mering and Minkowski, ${ }^{5}$ in 1892, proved that the depancreatinized 1890

5. Von Mering and Minkowski: Arch. f. exper. Path. u. Pharmakol. 26:371, 
dog has an extreme diabetes; while if a piece of pancreas be ingrafted under the skin of the dog, he remains sugar-free for two months, but on extirpation of the graft, diabetes is precipitated and the dog dies.

It has been generally conceded that the pancreas has an internal secretion that controls carbohydrate metabolism; and Baumel, Lemain and Lannois, Lepine and Audry with several other observers are satisfied that the Islands of Langerhans in the pancreas are the secreting cells of its internal secretion.

DeMeyer ${ }^{6}$ shows that the liver from a depancreatized animal, perfused with Ringer's solution can have storage of glycogen function restored by adding pancreatic extract. He does not say whether the addition of any other glandular extract will be similarly effective. Von Mering and Minkowski have shown that diabetes is not a nerve lesion; nor an alteration of liver function through impaired circulation; nor an impairment of digestion of carbohydrates.

Harley $^{7}$ assures us that the glycosuria is not due to injury of the nerves of the celiac plexus, but solely to "total arrest of pancreatic function," and adds that the entire pancreas, rather than the islands alone, plays the part.

Pathologists agree on the findings in diabetes.

Cecil, ${ }^{8}$ in 1908, reported very completely ninety cases of diabetes with pathologic-anatomic studies, and found that 79 per cent. of these cases had definite anatomic changes in the islands. Of these, 40 per cent. had a moderate sclerosis and 35 per cent. advanced sclerosis. Lydia DeWitt, ${ }^{9}$ in a large series of cases, observed that the Islands of Langerhans contain more connective tissue with advancing age - but this is characteristic of all parenchyma.

$\mathrm{Cecil}^{8}$ mentions one case in particular with marked pancreatic lipomatosis coming to necropsy. There had been no diabetes, yet only a small fraction of the parenchyma survived; which, however, compensated for the lost tissue in being very rich in well preserved Islands of Langerhans.

The islands in diabetes are found to be surrounded by thick fibrous sheaths. The fibrillary coating of insular capillaries is definitely increased in thickness, converting vessels to coarse septa which extend in from the capsule and anastomose at the center of the interacinar island. The cells forming the column show little change.

Considerable study has been made of other internal secreting organs with a view of finding a possible different source of material

6. DeMeyer: Arch. de physiol. 1909-1910, pp. 1-100.

7. Harley: Jour. Anat. and Physiol., London 26:204, 1891-1892.

8. Cecil (two papers) : Med. and Surg. Rep. Presb. Hosp., New York 8:173 and 217,1908 .

9. DeWitt: J. Exper. Med. 8:193, 1906. 
controlling carbohydrate metabolism. Cecil ${ }^{8}$ thought of this and mentions several cases of changes in the pituitary gland besides sclerosis of the Islands of Langerhans in diabetes. With stimulation of adrenals by way of the sympathetic nerves, MacKenzie ${ }^{10}$ found that glycogenolysis increased, and there was a hyperglycemia. It does not, however, cause a loss of glycolytic activity which is part of the altered metabolism in pancreatic diabetes. On extirpation of the adrenals in depancreatized dogs, the hyperglycemia disappears. There is no definite relation between the adrenal medulla and the Islands of Langerhans.

It is accepted that insufficient activity of the Islands of Langerhans will cause diabetes, but there are several other factors that may cause it, about which we as yet know nothing.

There are no records of the frequency of cirrhosis of the pancreas in syphilitics, but judging from the rapidity with which cirrhosis of all parenchyma occurs in this disease, it is not difficult to assume that the pancreas likewise suffers.

Warthin and Wilson, ${ }^{11}$ Laigne $^{12}$ and Antoine ${ }^{13}$ reported a relative frequency of the presence of syphilis in diabetics, but nothing has been said of the alteration of the blood chemistry in this type of case. The syphilitic diabetic is either diabetic because of his syphilis, or made much worse by it, and unquestionably the syphilitic diabetic has a much greater involvement of the Islands of Langerhans than the nonsyphilitic diabetic.

The diastatic activity of the blood of the ordinary syphilitic varies as normally; in the simple diabetic the diastatic activity is extremely high, ranging from 40 to 100 , usually around 60 or 80 , as Meyer and Killian ${ }^{1}$ also noted. But without exception those diabetics who are syphilitic have a low diastatic activity, while both types have varying degrees of hyperglycemia.

Each of the five syphilitic diabetics in our records had a notably low carbohydrate tolerance, and we have thus far been unable to get a syphilitic diabetic under sufficiently long observation to state whether his increased tolerance rises to normal after the syphilis is cured, or whether some permanent ferment injury has been done. In one case, however, the patient came into the hospital with diabetes and gangrenous foot, improved rapidly in health and the foot healed after two arsphenamin treatments, and his carbohydrate tolerance almost doubled.

10. MacKenzie, G. M.: Arch. Int. Med. 19:593, 1917.

11. Warthin and Wilson: Am. J. Med. Sc. 152:157, 1916.

12. Laignel: Rev. neurol., Paris 22:481, 1914.

13. Antoine: Arch. méd. d'angus 17:147, 1913. 
The syphilitic diabetic has the most extreme loss of carbohydrate tolerance, which, it is our personal belief, will be checked on cure of the syphilis, if the patient is given the same dietetic care that any diabetic should receive, keeping the hyperglycemia reduced to normal.

If it is possible to have a low diastatic activity and diabetes, then the disease does not depend solely on glycogenolysis, but may be due to the failure of the tissues to hold or to burn sugar.

It seems incredible that the Islands of Langerhans should secrete an activating agent for diastase that sometimes activates and sometimes inhibits; but this must be true if we accept the idea that pancreatic diabetes and syphilitic diabetes have the same cause - insufficiency of the secretion of the Islands of Langerhans - for in one case the diastatic activity is very high and in the other low. The only explanation we can offer for this is that the Islands of Langerhans secrete a substance inhibitory to the action of diastase, and thereby control its activity. If this is true, then the increased diastatic activity in pancreatic diabetes is due to destruction of the islands so great that there is no inhibiting agent of diastase secreted, and the diastase in the blood is superactive.

In the syphilitic diabetic, cirrhosis is not confined to the islands of the pancreas, but involves all parenchymatous tissue. This encroaches on the secreting cells which, in turn, are irritated and stimulated to excessive secretion. The diastase is inhibited to a greater degree, with resultant low diastatic activity. One never finds increased diastatic activity with a hypo- or normal glycemia, but it is not uncommon to find hyperglycemia and a low diastatic activity. So we conclude that the hyperglycemia of diabetes is due to another cause than increase of glycogenolysis alone, and it probably is something affecting the permeability of cell membranes to sugar and inhibition of glycogenesis, so that all the sugar remains in the blood, to be excreted, or a very small portion burned.

Table 1 gives data of seventeen cases, of which six patients are syphilitic. Of these six, only one was suspected of having syphilis; the other five were well symptomatically, with the exception of their diabetes. Each case of simple diabetes shows the greatly increased diastatic function and hyperglycemia, and the syphilitic diabetics are characterized especially by their hyperglycemia and low or normal diastatic function. Several of the nonsyphilitic diabetics are somewhat atypical, with high sugars and not excessively actice diastatic functions.

Case 2, for instance, was a business man, exhausted by the long strain of an exacting business. With a complete rest and tolerance dieting, he made a complete recovery and now has a normal blood chemistry and tolerance for carbohydrates. 
Case 4, a woman with a history of diabetes and deafness for four years, had a tolerance of $30 \mathrm{gm}$. of carbohydrates at the time the blood was taken, and was very weak. Improvement was striking with antisyphilitic treatment.

Case 1 was a ward patient brought in for gangrenous foot. $\mathrm{He}$ was given arsphenamin, and the foot healed uneventfully. The carbohydrate tolerance in this case increased from $35 \mathrm{gm}$. to 60 after the arsphenamin.

TABLE 1.-Diabetics

\begin{tabular}{|c|c|c|c|c|c|c|}
\hline Case & Sex & Age & Diagnosis & $\begin{array}{l}\text { Wasser- } \\
\text { mann }\end{array}$ & $\begin{array}{l}\text { Blood Sugar, } \\
\text { Mg. per } \\
100 \text { C.c. }\end{array}$ & $\begin{array}{l}\text { Diastatic } \\
\text { Function }\end{array}$ \\
\hline 1 & $\sigma^{\prime}$ & 60 & Diabetes............... & +++ & 400 & $20^{*}$ \\
\hline 2 & $\sigma$ & 48 & $\begin{array}{l}\text { Diabetes....................... } \\
\text { One month of rest and diet.......... }\end{array}$ & $\begin{array}{l}\text { Neg. } \\
\text { Neg. }\end{array}$ & $\begin{array}{l}298 \\
150\end{array}$ & $\begin{array}{l}38 \\
38\end{array}$ \\
\hline 3 & $\sigma$ & 28 & Diabetes....................... & +++ & 200 & $10^{*}$ \\
\hline 4 & $q$ & 36 & Diabetes..................... & +++ & 400 & $25^{*}$ \\
\hline 5 & $q$ & 65 & Diabetes.................... & Neg. & 334 & 66 \\
\hline 6 & $\sigma$ & 60 & Diabetes.... & Neg. & 349 & 69 \\
\hline 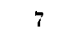 & q & 60 & Diabetes... & +++ & 400 & $20^{*}$ \\
\hline 8 & $\sigma^{*}$ & 46 & Diabetes..................... & Neg. & 405 & 75 \\
\hline 9 & $\sigma$ & 40 & Diabetes.................... & Neg. & 435 & 113 \\
\hline 10 & 우 & 40 & Diabetes....................... & Neg. & 400 & 102 \\
\hline 11 & $q$ & 45 & Dlabetes and nephritis............. & +++ & 421 & $5^{*}$ \\
\hline 12 & $0^{*}$ & 40 & Diabetes....................... & Neg. & 400 & 44 \\
\hline 13 & $0^{*}$ & 50 & Diabetes...................... & Neg. & 266 & 46 \\
\hline 14 & $\sigma^{\pi}$ & 51 & 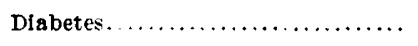 & ++ & $191^{\circ}$ & $25^{*}$ \\
\hline 15 & $q$ & 55 & 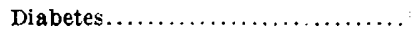 & Neg. & 261 & 62 \\
\hline 16 & $0^{\pi}$ & 60 & 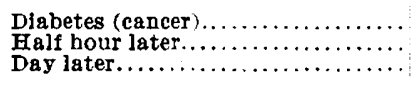 & $\begin{array}{l}\text { Neg. } \\
\text { Neg. } \\
\text { Neg. }\end{array}$ & $\begin{array}{l}266 \\
266 \\
500\end{array}$ & $\begin{array}{l}79 \\
60 \\
60\end{array}$ \\
\hline 17 & $\sigma^{\pi}$ & 61 & 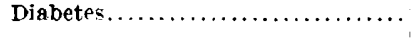 & Neg. & 235 & 33 \\
\hline
\end{tabular}

* Syphilitic.

Case 16 was a cancer patient with diabetes. His blood chemistry study was made before roentgen-ray treatment, one half hour after, and twenty-four hours after. The great increase in blood sugar on the day following the roentgen-ray treatment was due not to the roentgen ray, but to an excessive carbohydrate ingestion.

Case 17 is similar to Case 2 . In this instance the patient had what his doctor called an alimentary glycosuria. His blood sugar increases only during periods of fatigue and his diastatic function remains normal.

Case 9 had been kept well below his tolerance of $75 \mathrm{gm}$. of carbohydrate, no glycosuria and with normal blood sugar for two years. 


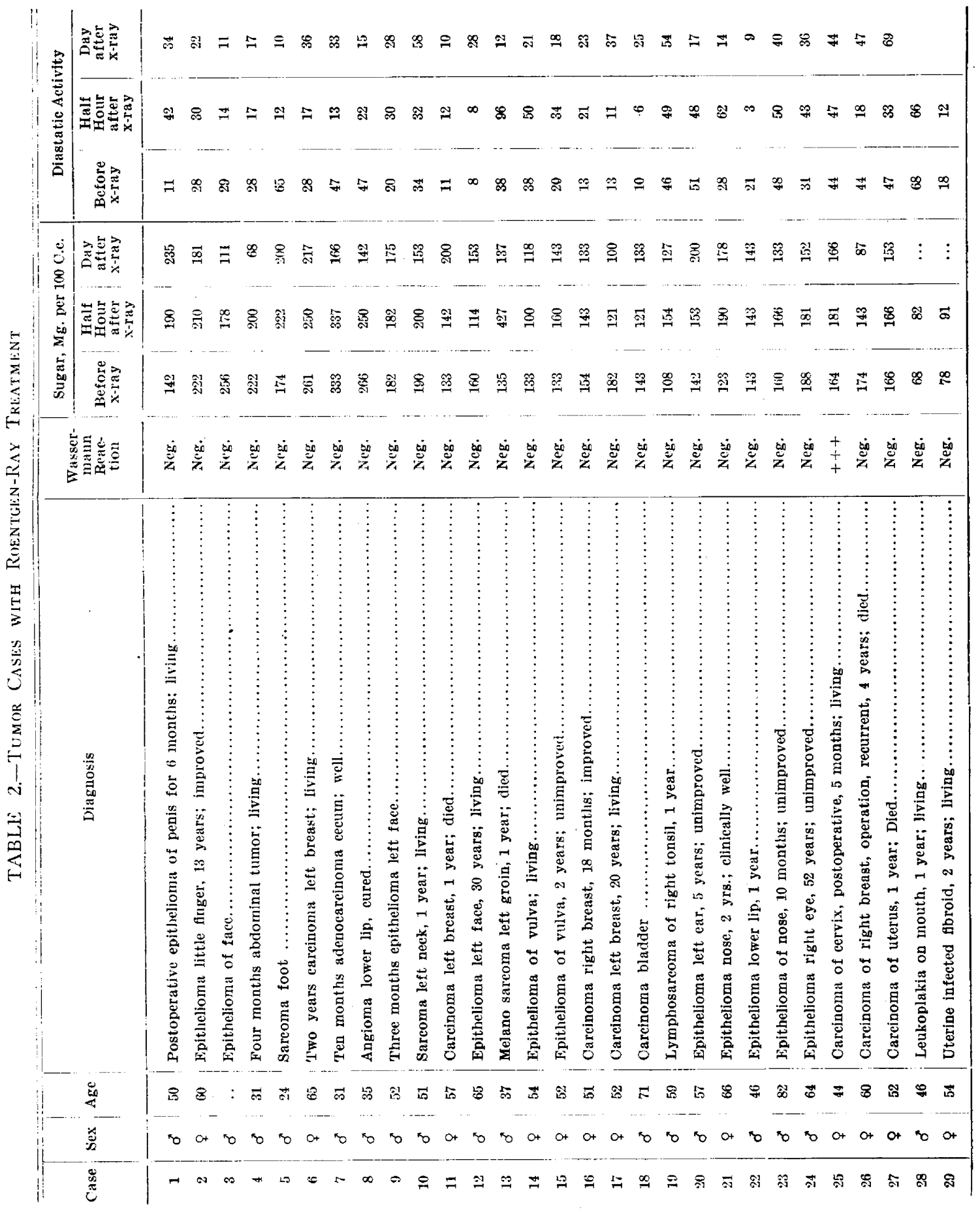


He had been able to do hard work in a steel mill during this time, and an attack of influenza temporarily broke his tolerance, when the blood study was made. It is steadily improving now, however, and the carbohydrate tolerance is picking up.

We studied twenty-nine cases of malignancy and the effect of roentgen ray on their blood chemistry (Table 2). We are utilizing the data of the sugar and diastatic function here, and the other studies are to be reported later.

The cancer patient shows no special feature of carbohydrate metabolism. There is a tendency to hyperglycemia, but in every instance this is due to the high carbohydrate diet these people had been getting, together with lack of exercise. The bed patient invariably shows deficient oxidative powers. The cancer patients studied were being treated with the roentgen ray, and the blood was obtained before exposure, one-half hour after and twenty-four hours after. Of the cases studied, several patients had slight renal lesions; but the majority were normal as to blood chemistry: 7 cases had hyperglycemia; 21 had normal sugar before roentgen ray; 13 had sugar increased one-half hour after; 15 had decreased one-half hour after; 9 had increased the day after; 19 had decreased the day after.

Those cases in which the sugars were lowest following roentgen ray treatment had received the largest doses, so we can say that the roentgen ray certainly increases oxidation of blood sugar, but this is true of any individual whether he has a malignant disease or not. In half of the cases the diastatic activity had increased one-half hour after roentgen-ray treatment, and in the rest there was a decrease. On the day following roentgen-ray exposure the diastatic activity of half of the cases studied had increased, and in the rest it had decreased. As the diastatic activity of patients treated with the roentgen ray under similar conditions did not show a consistent increase or decrease either one-half hour after or the day after roentgen-ray treatment, we can say that the rays have no special or permanent effect on the diastatic activity of the blood.

In the fifty-two miscellaneous malignant cases recorded in Table 3 the blood sugar varies with the diet and exercise of the patient.' The diastatic function has no special relation to any condition that could be considered specific or diagnostic for malignancy.

Those syphilitics with the additional disease of cancer do not necessarily have a low diastatic activity. On the other hand, many of the nonsyphilitic cases have extremely low diastatic activities.

Sixty-one miscellaneous cases (Table 4) show very much the same thing in their blood chemistry as regards the sugar and diastatic activity that the cancer cases show. 
TABle 3.-Cancer Cases Not Roentgen-Rayed

\begin{tabular}{|c|c|c|c|c|c|c|c|c|}
\hline Case & Sex & Age & Diagnosis & $\begin{array}{c}\text { Wasser- } \\
\text { mann } \\
\text { Reac- } \\
\text { tion }\end{array}$ & $\begin{array}{l}\text { Blood } \\
\text { Sugar, } \\
\text { Mg.per } \\
100 \text { C.c. }\end{array}$ & $\begin{array}{c}\text { Dias- } \\
\text { tatic } \\
\text { Func- } \\
\text { tion }\end{array}$ & $\begin{array}{c}\text { Dura- } \\
\text { tion }\end{array}$ & $\begin{array}{l}\text { Present } \\
\text { Condition }\end{array}$ \\
\hline 1 & q & 48 & Myoma................... & ++ & 166 & 17 & $1 \mathrm{yr}$. & Died \\
\hline 2 & $\delta$ & 70 & Epithelioma of face......... & Neg. & 166 & 18 & $1 \mathrm{gr}$. & Died \\
\hline 3 & $q$ & 60 & Carcinoma right breast..... & Neg. & $\dot{250}$ & 30 & 5 yr. & Died \\
\hline 4 & $\sigma^{\prime}$ & 27 & Syphilis; granuloma........ & $++t$ & 200 & 30 & $14 \mathrm{mo}$. & Clinicaly well \\
\hline 5 & $\sigma^{7}$ & 50 & Epithelioma right cheek.... & Neg. & 188 & 38 & $2 \mathrm{gr}$. & Well \\
\hline 6 & q & 36 & Carchoma uterus........... & +++ & 274 & 25 & 5 mo. & Died \\
\hline 7 & $\delta$ & 63 & Papilloma bladder......... & Neg. & 148 & 26 & $3 \mathrm{yr}$. & Unimproved \\
\hline 8 & $q$ & 39 & Postoperative carcinoma & Neg. & 200 & 40 & I2 yr. & Unimproved \\
\hline 9 & q & 65 & Carcinoma breast.......... & Neg. & 118 & 23 & 2 yr. & Died \\
\hline 10 & ९ & 61 & Eplthelioma nose.......... & Neg. & 160 & 26 & 1 yr. & Well \\
\hline 11 & 9 & 61 & $\begin{array}{c}\text { Postoperative, recurrent } \\
\text { carcinoma left breast }\end{array}$ & Neg. & 117 & 7 & $7 \mathrm{mos}$ & Died \\
\hline 12 & $\sigma^{7}$ & 41 & Epithelioma lower gum..... & Neg. & 153 & 22 & $6 \mathrm{mo}$. & Unimproved \\
\hline 13 & $\delta$ & 41 & Epithelioma lip, lower...... & Neg. & 130 & 40 & $4 \mathrm{yr}$. & Unimproved \\
\hline 14 & 8 & 57 & Epithelioma ear, left........ & Neg. & 133 & 28 & $5 \mathrm{yr}$. & Living \\
\hline 15 & $\varphi$ & 53 & Carcinoma (colloid) rectum & Neg. & 153 & 26 & $1 \mathrm{gr}$. & Living \\
\hline 16 & $d$ & 18 & Epithelioma right upper & Neg. & 129 & 16 & $6 \mathrm{mo}$. & Died \\
\hline 17 & 우 & 52 & Carcinoma uterus.......... & Neg. & 153 & 19 & $1 \mathrm{yr}$. & Died \\
\hline 18 & $q$ & 49 & Carcinoma uterus............ & $\underset{(8 / 14 / 18)}{\text { Neg. }}$ & 123 & 25 & 9 wk. & Living \\
\hline 19 & 우 & 49 & $\ldots \ldots \ldots \ldots \ldots \ldots \ldots \ldots$ & $(8 / 24 / 18)$ & 136 & 14 & & \\
\hline 20 & $q$ & 49 & 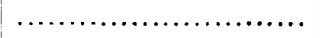 & $(7 / 12 / 18)$ & 117 & 31 & & \\
\hline 21 & $q$ & 62 & Epithelioma shoulder, left.. & Neg. & 235 & 47 & $30 \mathrm{yr}$. & Unimproved \\
\hline 22 & $q$ & $5 \tilde{5}$ & $\begin{array}{c}\text { Melanosarcoma Archilles } \\
\text { tendon }\end{array}$ & $+?$ & 160 & 48 & $6 \mathrm{yr}$. & Operated; well \\
\hline 23 & q & 65 & Carcinoma esophagus...... & Neg. & 181 & 44 & 1 yr. & Living \\
\hline 24 & $\sigma^{*}$ & 49 & $\begin{array}{c}\text { Syphilis and epithelioma } \\
\text { soft palate }\end{array}$ & $\left(10 /+\frac{+}{4 / 18}\right)$ & 190 & 50 & 4.5 mo. & Died \\
\hline 25 & $\sigma^{\prime}$ & 49 & $\ldots \ldots \ldots \ldots \ldots \ldots \ldots \ldots \ldots \ldots$ & $(8 / 21 / 18)$ & 118 & 40 & & \\
\hline 26 & q & 51 & Carcinoma cervix........... & Neg. & 172 & 38 & $1 \mathrm{gr}$. & Died \\
\hline 27 & $q$ & 42 & Round cell sarcoma......... & Neg. & 166 & 66 & $1 \mathrm{gr}$. & Living \\
\hline 28 & $\sigma^{*}$ & 80 & Carcinoma bladder.......... & Neg. & 400 & 80 & $1 \mathrm{yr}$. & Living \\
\hline 29 & ᄋ & 45 & Carcinoma stomach....... & Neg. & 286 & 76 & $4 \mathrm{mo}$. & Died \\
\hline 30 & 우 & 60 & Epithelioma tongue......... & Neg. & 166 & 46 & $6 \mathrm{mo}$. & Untreated \\
\hline 31 & $q$ & 61 & Pyloric ulcer, obstruction... & Neg. & 154 & 39 & all life & Living \\
\hline 32 & $\sigma$ & 53 & Mediastinal tumor............ & Neg. & 285 & 23 & $3 \mathrm{mo}$. & Unimproved \\
\hline 33 & $\sigma^{\prime}$ & 39 & Carcinoma of breast........ & Neg. & 250 & 30 & $2 \mathrm{yr}$. & No recurrence \\
\hline 34 & 웅 & 60 & Epithelioma finger, left & Neg. & 202 & 15 & $13 \mathrm{yr}$. & Improved \\
\hline 35 & q & 39 & Carcinoma cervix.......... & ++ & 166 & 47 & $6 \mathrm{mo}$. & Clinically well \\
\hline 36 & q & $4 \bar{\jmath}$ & Carcinoma cervix............ & + & 187 & 30 & $4 \mathrm{yr}$ & Improved \\
\hline 37 & q & 59 & $\begin{array}{l}\text { Lymphosarcoma, probable } \\
\text { primary in tonsil }\end{array}$ & Neg. & 178 & 25 & $18 \mathrm{mo}$. & Unimproved \\
\hline 38 & 우 & 43 & Adenocarcinoma uterus.... & Neg. & 238 & 18 & $10 \mathrm{yr}$. & Living \\
\hline
\end{tabular}


Table 3.-Cancer Cases Not Roentgen-Rayed-(Continued)

\begin{tabular}{|c|c|c|c|c|c|c|c|c|}
\hline Case & Sex & Age & Diagnosis & $\begin{array}{c}\text { Wasser- } \\
\text { mann } \\
\text { Reac- } \\
\text { tion }\end{array}$ & $\begin{array}{l}\text { Blood } \\
\text { Sugar, } \\
\text { Mg.per } \\
\text { 100 C.c. }\end{array}$ & $\begin{array}{l}\text { Dias- } \\
\text { tatic } \\
\text { Func- } \\
\text { tion }\end{array}$ & $\begin{array}{c}\text { Dura- } \\
\text { tlon }\end{array}$ & $\begin{array}{l}\text { Present } \\
\text { Condition }\end{array}$ \\
\hline 39 & 우 & 76 & Epithelioma vulva......... & Neg. & 149 & 44 & $8 \mathrm{mo}$ & Living \\
\hline 40 & q & 51 & Carcinoma ovary.......... & Neg. & 181 & 21 & 2 yr. & Living \\
\hline 41 & $\sigma$ & 62 & Gumma (bridge of nose).... & $\begin{array}{c}\text { Neg. } \\
(10 / 15 / 18)\end{array}$ & 166 & 24 & $1 \mathrm{yr}$. & Living \\
\hline 42 & $\sigma$ & . & $\ldots \ldots \ldots \ldots \ldots \ldots \ldots \ldots \ldots$ & $(10 / 22 / 18)$ & 244 & 16 & & \\
\hline 43 & $\delta$ & $\cdots$ & 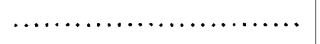 & $(11 / 9 / 18)$ & 181 & 64 & & \\
\hline 44 & 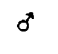 & 74 & $\begin{array}{l}\text { Epithelioma epltrochlear } \\
\text { reglon, prickle cell }\end{array}$ & + & 244 & 31 & $5 \mathrm{mo}$ & Living \\
\hline 45 & $q$ & 29 & Carcinoma uterus........... & Neg. & 200 & 40 & $7 \mathrm{mo}$. & Unimproved \\
\hline 46 & 우 & 52 & Sarcoma of neck........... & ++ & 181 & 36 & $4 \mathrm{mo}$. & Clinically well \\
\hline $4 i$ & $\sigma$ & 57 & $\begin{array}{c}\text { Epitbelioma branchial re- } \\
\text { mains }\end{array}$ & ++ & 142 & 24 & 4 mo. & Unimproved \\
\hline 48 & 우 & 34 & Angioma eye............... & Neg. & 166 & 15 & 32 yr. & Living \\
\hline 49 & 우 & 66 & Carcinoma uterus........... & Neg. & 181 & 44 & $4 \mathrm{yr}$ & Improved \\
\hline 50 & q & 31 & Splenic anemia... & Neg. & 285 & 23 & $1 \mathrm{mo}$. & Unimproved \\
\hline 51 & $\varphi$ & 65 & Epithelioma of nose.... & Neg. & 200 & 40 & $1 \mathrm{yr}$. & Well \\
\hline 52 & 0 & . & Epithelioma of scrotum.... & Neg. & 250 & 50 & $5 \mathrm{yr}$. & Died \\
\hline
\end{tabular}

TaBle 4.-Miscellaneous Cases

\begin{tabular}{|c|c|c|c|c|c|c|}
\hline Case & Sex & Age & Diagnosis & $\begin{array}{l}\text { Wasser- } \\
\text { mann }\end{array}$ & $\begin{array}{c}\text { Blood Sugar, } \\
\text { Mg. per } \\
100 \text { C.c. }\end{array}$ & $\begin{array}{l}\text { Diastatic } \\
\text { Function }\end{array}$ \\
\hline 1 & $\sigma^{*}$ & 55 & 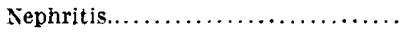 & Neg. & 298 & 40 \\
\hline 2. & $\sigma^{7}$ & 25 & 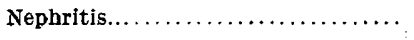 & Neg. & 105 & 41 \\
\hline 3 & $q$ & 42 & Nephritis.... . & Neg. & 181 & 97 \\
\hline 4 & $\phi$ & 50 & 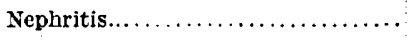 & Neg. & 202 & 39 \\
\hline $\mathbf{5}$ & 8 & 50 & 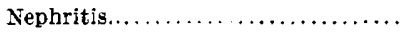 & ++ & 148 & 27 \\
\hline 6 & $\sigma^{\prime \prime}$ & 45 & 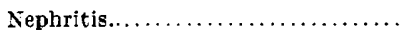 & Neg. & 154 & 9 \\
\hline 7 & $q$ & 55 & Nephritis....................... & Neg. & 142 & 9 \\
\hline 8 & $q$ & 60 & Nephritis.......................... & Neg. & 87 & 22 \\
\hline 9 & $\delta$ & 50 & Nephritis........................... & Neg. & 259 & 17 \\
\hline 10 & $\sigma^{7}$ & 45 & 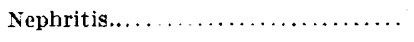 & Neg. & 250 & 8 \\
\hline 11 & q & 47 & Nephritis...................... & Neg. & 175 & 26 \\
\hline 12 & $q$ & 49 & Nephritis.......................... & $+\div$ & 307 & 11 \\
\hline 13 & 우 & 55 & 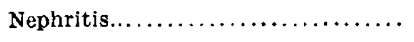 & Neg. & 222 & 15 \\
\hline 14 & $q$ & 52 & Arthritis deformans.............. & Neg. & 223 & 27 \\
\hline 15 & $\sigma^{\prime}$ & 38 & Arteriosclerosis................. & Neg. & 164 & 39 \\
\hline 16 & $\sigma$ & 62 & Depressive insanity $\ldots \ldots \ldots \ldots \ldots$ & Neg. & 333 & 33 \\
\hline 17 & 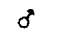 & 27 & Hemorrhagic retinitis............. & Neg. & 200 & 40 \\
\hline 18 & $d$ & 38 & Hemorrhagic retinitis............. & Neg. & 111 & 26 \\
\hline 19 & 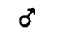 & 30 & Hemorrhagie retinitis............. & Neg. & 181 & 16 \\
\hline 20 & $\delta$ & 38 & Exophthalmic goiter. ............. & Neg. & 250 & 30 \\
\hline 21 & ㅇ & 34 & Exophthalmic goiter................ & Neg. & 185 & 30 \\
\hline
\end{tabular}


TABLE 4.-Miscellaneous Cases-(Continued)

\begin{tabular}{|c|c|c|c|c|c|c|}
\hline Case & Sex & Age & Diagnosis & $\begin{array}{l}\text { Wasser- } \\
\text { mann }\end{array}$ & $\begin{array}{c}\text { Blood Sugar, } \\
\text { Mg. per } \\
100 \text { c.c. }\end{array}$ & $\begin{array}{l}\text { Diastatic } \\
\text { Function }\end{array}$ \\
\hline 22 & $q$ & 34 & Exophthalmic goiter............ & Neg. & 140 & 25 \\
\hline 23 & 우 & 34 & Exophthalmic goiter........... & Neg. & 166 & 44 \\
\hline 24 & q & 34 & Exophthalmic goiter........... & Neg. & 80 & 13 \\
\hline 25 & q & 34 & Nervous and tired............... & Neg. & 154 & 69 \\
\hline 26 & $\sigma^{2}$ & 45 & Nervous and tired.............. & Neg. & $28 \mathfrak{5}$ & 49 \\
\hline 27 & 우 & 55 & Nervous and tired.............. & Neg. & 143 & 35 \\
\hline 28 & 우 & 55 & Nervous and tired................. & Neg. & 250 & 50 \\
\hline 29 & q & 38 & Nervous and tired................ & Neg. & 192 & 51 \\
\hline 30 & 우 & 40 & Nervous and tired................. & Neg. & 166 & 24.8 \\
\hline 31 & q & 52 & 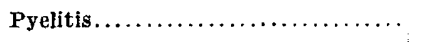 & Neg. & 146 & 22 \\
\hline 32 & $q$ & 36 & Pyelitis.............. & Neg. & 143 & 24 \\
\hline 33 & $q$ & 36 & Epilepsy.................... & Neg. & 111 & 35 \\
\hline 34 & $\delta$ & 65 & Cardiorenal disease................. & Neg. & 142 & 38 \\
\hline 35 & $q$ & 60 & Cardiorenal disease............. & Neg. & $14 i$ & 31 \\
\hline 36 & $d$ & 38 & Headache (autointoxication)...... & Neg. & 111 & 34 \\
\hline 37 & $\sigma$ & 41 & 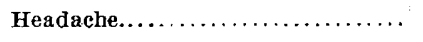 & Nieg. & 133 & 30 \\
\hline 38 & $q$ & 48 & 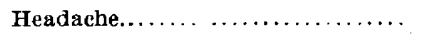 & Neg. & 142 & 50 \\
\hline 39 & $0^{\circ}$ & 55 & Headache.................... & Neg. & 309 & 46 \\
\hline 40 & $\sigma^{*}$ & 40 & Headache........... & Neg. & 200 & 93 \\
\hline 41 & $q$ & 45 & 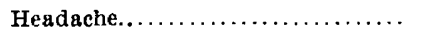 & Neg. & 162 & 67 \\
\hline 42 & 8 & 30 & 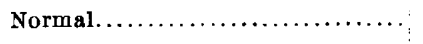 & Neg. & 148 & 20 \\
\hline 43 & $q$ & 56 & 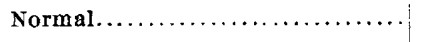 & Neg. & 106 & 22 \\
\hline 44 & $\sigma^{7}$ & 53 & 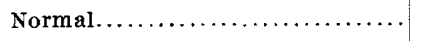 & Neg. & 266 & 13 \\
\hline 45 & 우 & 27 & Normal..... & Neg. & 100 & 25 \\
\hline 46 & $q$ & 23 & Normal........... & Neg. & 200 & 40 \\
\hline 47 & $q$ & 25 & Normal........... & Neg. & 123 & 32 \\
\hline 48 & $q$ & 25 & Normal....... & Neg. & 188 & 7 \\
\hline 49 & 우 & 25 & 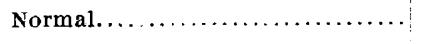 & Neg. & 143 & 28 \\
\hline 50 & $\sigma$ & 60 & Myocarditis........................ & Neg. & 166 & 24 \\
\hline 51 & $\sigma$ & 55 & Tuberculous pleurisy .............. & Neg. & 133 & 53 \\
\hline 52 & q & 52 & High blood pressure............... & Neg. & 156 & 46 \\
\hline 53 & $\sigma$ & 35 & 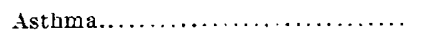 & Neg. & 145 & 36 \\
\hline 54 & 8 & 40 & 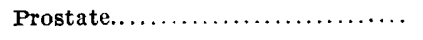 & Neg. & 170 & 56 \\
\hline 55 & 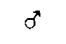 & 45 & Glaucoma.......................... & Neg. & 153 & 22 \\
\hline 56 & $\sigma$ & 40 & Glaucoma........................ & Neg. & 200 & 93 \\
\hline 57 & $q$ & 50 & 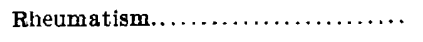 & Neg. & 166 & 47 \\
\hline 58 & $\sigma^{\pi}$ & 32 & Rheumatism $\ldots \ldots \ldots \ldots \ldots \ldots$ & Neg. & 121 & 27 \\
\hline 59 & $q$ & 50 & 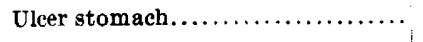 & Neg. & 154 & 49 \\
\hline 60 & ? & 62 & Tingling in fingers.................... & Neg. & 166 & 24 \\
\hline 61 & $\sigma$ & 35 & 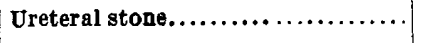 & Neg. & 200 & 16 \\
\hline
\end{tabular}


The nephritics have a retention of sugar depending on the severity of their lesion. The diastatic activity varies as in health.

In the case of arthritis deformans the patient had a general retention which was entirely corrected by diet.

The depressive insanity patient had a blood sugar of 333 and no glycosuria; it was probably due to diet and restraint in bed, and in his kidneys a high threshold of excretion for sugar.

The cases of hemorrhagic retinitis and glaucoma gave moderately increased blood sugars, and in one case, No. 56, an enormously increased diastatic activity.

Exophthalmic goiter cases gave high blood sugars, and indefinitely varying diastatic activity. Patients with pyelitis, cardiorenal lesion, epilepsy, myocarditis, tuberculous pleurisy, asthma, hypertrophied prostate, rheumatism and ulcer of the stomach, have normal blood sugar and normal diastatic activity.

The group of persons having no symptoms but those of overwork show a lack of oxidation of their sugar and at the same time a high diastatic activity. This may be traceable partly to an accumulation of unoxidized materials in the blood.

Eight normal persons were studied and each had normal blood chemistry, with the exception of two whose high blood sugar was purely dietary.

The blood sugar and diastatic activity are very variable, and up to the present their chief value lies in their definite relation to diet.

In our work we have had an opportunity to study nine eclamptics carefully (Table 5), and in this series there were no syphilitics. Glycosuria and hyperglycemia during the latter months of pregnancy are very frequent. These cases show only a moderate hyperglycemia, although it is at a time in pregnancy when one would expect the blood sugar to be much higher.

TABLE 5.-Cases of Pregnancy

\begin{tabular}{|c|c|c|c|c|c|c|}
\hline Case ! & Sex & Age & Diagnosis & $\begin{array}{l}\text { Wasser- } \\
\text { mann }\end{array}$ & $\begin{array}{c}\text { Blood Sugar, } \\
\text { Mg. per } \\
100 \text { C.c. }\end{array}$ & $\begin{array}{l}\text { Diastatic } \\
\text { Function }\end{array}$ \\
\hline 1 & q & 28 & Eclampsia...................... & Neg. & 200 & 42 \\
\hline 2 & 우 & 27 & Pernicious vomiting............... & Neg. & 181 & 30 \\
\hline 3 & q & 29 & 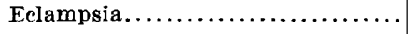 & Neg. & 165 & 27 \\
\hline 4 & $q$ & 30 & Eclampsia...... & Neg. & 142 & 11 \\
\hline 5 & $q$ & 28 & Eclampsia........................ & Neg. & 184 & 20 \\
\hline 6 & $q$ & 20 & Eclampsia...................... & Neg. & 167 & 38 \\
\hline 7 & 우 & 26 & Eclampsia...... & Neg. & 160 & 25 \\
\hline 8 & q & 25 & Eclampsia.$\ldots \ldots \ldots \ldots \ldots \ldots \ldots$ & Neg. & 160 & 16 \\
\hline 9 & $q$ & 26 & Eclampsia $\ldots \ldots \ldots \ldots \ldots \ldots \ldots \ldots$ & Neg. & 125 & 25 \\
\hline
\end{tabular}


The diastatic activity is normal in all except the first woman, who had a marked glycosuria.

The blood sugar and diastatic function behave very much as in the normal individual - affected by diet or renal insufficiency; but nothing else that is demonstrable in these few cases.

\section{CONCLUSIONS}

1. There is a low diastatic activity in diabetes associated with syphilis.

2. The internal secretion of the pancreas is probably inhibitory to the activity of the diastase in the blood.

3. Exposure to roentgen rays for either long or short periods of time does not alter the activity of the diastase, but in some cases temporarily lowers the sugar content of the blood.

4. There is nothing especially characteristic of either the blood sugar or diastase of the cancer patient at any stage of his disease.

5. Miscellaneous nondiabetic cases show normal sugar in the blood with normal or low diastatic activity; or high sugar with increased or low diastatic activity; but never low sugar with high diastatic activity.

6. The diastatic activity tends to increase with rising sugar in the blood, especially with a dietary glycemia.

7. In dietary correction of a hyperglycemia the diastatic activity decreases with the sugar, whether in a diabetic or not.

Further studies on the problem of diastase are in progress. 